\title{
Accounting
}

\section{Does industry expertise at engagement partner and audit firm level matter in emerging market? Evidence from Indonesia}

\section{Antonius Herusetya $a^{a^{*}}$ and Meiliana Jaunanda ${ }^{a}$}

${ }^{a}$ Faculty of Economics and Business, University of Pelita Harapan, Tangerang 15810, Banten, Indonesia

\begin{tabular}{l}
\hline C H R O N I C L E \\
\hline Article history: \\
Received: September 25, 2020 \\
Received in revised format: \\
September 302020 \\
Accepted: January 10, 2021 \\
Available online: \\
January 11, 2021 \\
\hline Keywords: \\
Aggressive earnings management \\
Modified audit opinion \\
Industry specialization \\
Engagement partner \\
Audit firm \\
Audit quality
\end{tabular}

\section{Introduction}

Studies on individual audit partners have begun to increase lately (Lennox \& Wu, 2018; Wang et al., 2015; Burke et al., 2019; Cianci et al., 2017; Dao et al., 2018). The increase in individual partner studies began when PCAOB considered public accounting firms to disclose information about individual partners to the public in the United States of America. At the same time, studies outside the United States found evidence that individual audit partners influence audit quality (Lee et al., 2019; Gul et al., 2017; Gul et al., 2013; Wang et al., 2015; Taylor, 2011). Gul et al. (2013), for example, found that individual auditors have an influence on audit quality economically both in large and small audit firms. Others found that the earnings response coefficient has a positive association with audit firms' quality of engagement partners (Abodia et al., 2015). Previous studies also found that the market responds to higher earnings when there is a shift of partners or auditors of lower quality to partners from higher audit firms (Abodia et al., 2015; Knechel et al., 2007). Furthermore, individual partner studies are also related to

* Corresponding author. Tel.: +628159032288

E-mail address: antonius.herusetya@uph.edu (A. Herusetya) 
gender issues (Lee et al., 2019; Burke et al., 2019; Ittonen et al., 2013; Lennox and Wu, 2018). Industry specialization is a measure of audit quality (Ji et al., 2019; Fargler et al., 2019; Stein, 2019; Herusetya, 2009a; 2009b; 2012; Knechel et al., 2007; Krishnan, 2003; Balsam et al., 2003). Previous studies used industry specialization at an audit firm level without distinguishing the audit quality from audit firms with their respective engagement partners (Stein, 2019; Herusetya, 2009a; 2009b). There are not many studies currently in industry specialization of engagement partners in the emerging market, except for Taiwan (e.g., Hsieh \& Lin, 2016; Chi \& Chin, 2011). Chi and Chin (2011), in a study in Taiwan, found that both industry specialization at the firm level and partner level has a negative effect on discretionary accruals. They also found evidence that industry specialization at the partner level, i.e., the signing auditor, is more pronounced to issue modified audit opinion (MAO) than industry specialization at a firm level. They concluded that industry specialists were not homogeneous among partners within the same audit firm, both measured from the accrual analysis and modified audit opinion (MAO). Hsieh and Lin (2016), with the same study in Taiwan, found that the industry specialization at the engagement partner level is more reliable than the industry specialization at the audit firm level. They found that engagement partners with industry specialization would accept fewer clients with high financial risks than industry specialization at audit firm level. This study is different from previous research because it was conducted in Indonesia as an emerging market with a low litigation environment compared to studies in other developed countries (e.g., Gul et al., 2017; Lee et al., 2019). Most studies on industry specialization at partner level have been conducted with the Taiwanese audit market (e.g., Chi \& Chin, 2011; Chin \& Chi, 2009; Abodia et al., 2015; Hsieh \& Lin, 2016). Chi and Chin (2011) use listed firms' data in Taiwan with different conditions with Indonesia, where one engagement partner only signs each audit report. Whereas auditors who sign audit reports in Taiwan consist of lead auditors and concurring auditors, both can have an industrial specialization, but may also not have an industry specialization. The motivation for this study is for the following reasons. First, the enactment of government regulation (i.e., Peraturan Pemerintah No. 20 Tahun 2015) regarding the maximum tenure of the audit engagement partner to increase the audit quality has not been much investigated. This study investigates the audit quality at the partner level and firm-level before and after that enactment. Second, as far as the author observes, there have been no studies investigating audit quality in terms of industry specialization at audit firm-level and engagement partner level in Indonesia as an emerging country. Chin and Chi (2009) found that the restatement of financial statements occurs less in partners with industry expertise, but they find no evidence that specialization at audit firm level is associated with the restatements of financial statements. They conclude that industry specialization at the audit firm level does not automatically indicate a higher audit quality if their partners' expertise does not accompany it. This study investigates industry specialization, both at audit firm-level and partner level in Indonesia, that is different from the Taiwan condition. Third, Defond and Zhang (2014) suggest using various measures in audit quality. This study uses accrual and real earnings management at an extreme level (Greiner et al., 2017) and modified audit opinion (Pujilestari \& Herusetya, 2013; Herusetya, 2012). Engagement partners and audit firms with industry expertise are expected to be able to detect earnings management behavior at the aggressive level, which has implications for engagement audit risk, as well as are associated with issuing more modified audit opinions than engagement partners and audit firms without industry expertise.

\section{Literature review and hypothesis development}

\subsection{Industry specialization at engagement partner level and audit firm level, and earnings management}

Audit quality in most studies is defined as "the market-assessed joint probability that a given auditor will both detect in the client's accounting system, and report the breach" (e.g., DeAngelo, 1981). Auditors are expected to not only find and report client adherence to financial reporting standards but also "how faithfully the financial statements reflect the firm's underlying economic events" (Defond \& Zhang, 2014 p. 280). High audit quality will increase the credibility that the financial statements reflect this. Conversely, the quality of financial statements can decline when management performs earnings management, both in accrual earnings management and real earnings management, so that earnings quality becomes less credible (Dechow et al., 2010). Auditor industry specialization, which is generally measured by industry-based concentration, is one measure of audit quality because auditors with industry specialization have the competence and reputation incentives to provide high audit quality (Stein, 2019; Defond \& Zhang, 2014; Balsam et al., 2003). Previous studies generally support that audit firms with industry expertise auditors have a higher capability to detect earnings management than audit firms who do not have this expertise (Defond and Zhang, 2014; Balsam et al., 2003; Krishnan, 2003; Gul et al., 2009). The direction of further studies on auditor competence no longer focuses on factors of industry specialization at audit firm level, but rather on individual auditor or engagement partner level (Hsieh \& Lin, 2016; Defond \& Zhang, 2014; Gul et al., 2013). Hsieh and Lin (2016), and Chin and Chi (2009), for example, found that audit quality proxy using partner-level industry specialists are more reliable than firm-level industry specialists. Recent studies have found that engagement partners' industry specialization influences the quality of financial statements (Ittonen et al., 2014; Chi \& Chin, 2011; Reichelt \& Wang, 2010; Chin \& Chi, 2009). Using data from public companies in Finland, Ittonen et al. (2014), for example, found that partners with industry expertise who was handling three to six public companies were associated with smaller accruals. Chi and Chin (2011) found that both industry specialization at partner and firm-level were associated with smaller discretionary accruals. 
Real earnings management, especially at an aggressive level, tends to make auditors expand their audit efforts and detect client business risks and other procedures performed at the planning stage (Greiner et al., 2017). The reason auditors can reveal real earnings management can be seen in Greiner et al. (2017). Greiner et al. (2017) uses the measurement of real earnings management at an aggressive level to explain the level of real earnings management at the highest income-increasing level of observation data, i.e., the highest quintile of each industry in each year. Aggressive real earnings management is expected to be revealed at the planning stage. With the same presumption, high audit quality through engagement partners and audit firms with industry specialization can lessen real transaction-based earnings management, in addition to the accrual- based earnings management.

Based on the above arguments, this paper tests the following hypotheses:

H1a. Industry specialization at engagement partner level is negatively related to accrual earnings management. H1b. Industry specialization at audit firm level is negatively related to accrual earnings management.

$\mathrm{H} 2 \mathrm{a}$. Industry specialization at engagement partner level is negatively related to real earnings management. $\mathrm{H} 2 \mathrm{~b}$. Industry specialization at audit firm level is negatively related to real earnings management.

\subsection{Industry specialization at partner engagement and audit firm level, and modified audit opinion}

The studies of auditor industry specialization found an association with high audit quality proxies, including going concern opinion (Lim and Tan, 2008; Reichelt and Wang, 2010). For example, Reichelt and Wang (2010) found that national and cityspecific industry specialization tends to issue going-concern opinions. Previous studies in Taiwan showed that partners with industry expertise, i.e., signing auditors- lead and concurring auditors were associated with issuing more modified audit opinions (MAO) (Chi \& Chin, 2011). Modified audit opinion (MAO) is generally used as an alternative to going concern opinion (GCO), which is prevalent in the United States (e.g., Chan \& Wu, 2011). This study suspects that high audit quality from industry specialization at engagement partner and audit firm level is associated more with the tendency for issuing modified audit opinion. This study proposes the following hypothesis to address those issues:

H3a. Industry specialization of engagement partner level is positively related to the modified audit opinion.

$\mathrm{H} 3 \mathrm{~b}$. Industry specialization of audit firm level is positively related to the modified audit opinion.

\section{Research design}

\subsection{Data and sample selection}

This study collected financial data from listed companies on the Indonesia Stock Exchange (IDX), covering three industries, i.e., primary and chemical industries, various industries, and consumer goods industries. The data source comes from annual report data published on the company websites, audit reports, audited financial statements, and reports published by the Indonesia Stock Exchange from 2014 to 2018. Audit report data, both audited by the Big Four and non-Big Four with each opinion signed by an engagement partner from each audit firm. While industry specialization data is obtained using the market concentration of each industry, both at the audit firm level and partner level. The final data sample used for each model consists of 570 firm-year observations reported in Table I. All continuous data are winsorized with mean \pm two standard deviations each year related.

\section{Table 1}

Sample selection

\begin{tabular}{l}
\hline Description \\
\hline Firm-year observations in primary and chemical industries, various industries, and consumer goods industries during $2014-2018$ \\
Less: \\
Observations with missing audit opinion information \\
Observations with financial statements stated in foreign currency \\
Observations with missing financial information in 2013 \\
Final sample
\end{tabular}

\subsection{Regression models and variable measurements}

The hypothesis of this study examines the audit quality of engagement partner and audit firm with industry specialization. This study uses various measures of audit quality, i.e., accrual-based and real-based earnings management, and modified audit opinion. The following model is used to test hypothesis H1a and H1b: 


$$
\begin{aligned}
& \mathrm{Q}_{1 D A}, \mathrm{t}=\beta_{1}+\beta_{2} \text { PARTNER_SPCL }_{i, t}+\beta 3 \text { FIRM_SPCLi,t }_{-}+\beta 4 \text { CI_PARTNER }_{i, t}+\beta 5_{-} \text {CI_FIRM }_{i, t} \\
& +\beta 6 \text { BIGFOUR }_{i, t}+\beta \text { SIZE }_{i, t}+\beta \text { LEVERAGE }_{i, t}+\beta \text { LOSS }_{i, t}+\beta 10 \text { CFO }_{i, t} \\
& +\beta 1 \text { GROWTH }_{i, t}+\beta 12 \text { BTM }_{i, t}+\beta 13 \text { ROA }_{i, t}+\beta 14 \text { DROA }_{i, t}+\beta 15 \text { AGE }_{i, t} \\
& +\beta 16 \text { Q1REM }_{i, t}+\beta 18 \text { TACC }_{i, t}+\delta_{j} \text { YEAR }+\sigma_{\mathrm{k}} \text { INDUSTRY }+\varepsilon i, t
\end{aligned}
$$

where: PARTNER_SPCL and FIRM_SPCL are audit quality variables of engagement partners and audit firms with industry specialization. The negative values of $\beta_{2}$ and $\beta_{4}$ in Eq. (1) indicate the expectations of the hypotheses H1a and H1b, that the quality of individual audit partner and audit firm with industry expertise has a negative association with aggressive discretionary accruals (Q1DA). Discretionary accruals are the most commonly used audit quality proxy. This study follows Tucker and Zarowin (2006) and Greiner et al. (2017) who use the Jones (1991) discretionary accrual model that has been modified by Dechow et al. (1995) as follows:

$$
\mathrm{TACC}_{\mathrm{i}, \mathrm{t}} / \mathrm{TA}_{\mathrm{i}, \mathrm{t}-1}=\delta_{0}+\delta_{1} 1 / \mathrm{TA}_{\mathrm{i}, \mathrm{t}-1}+\delta_{2} \mathrm{GPPE}_{\mathrm{i}, \mathrm{t}} / \mathrm{TA}_{\mathrm{i}, \mathrm{t}-1}+\delta_{3} \Delta \mathrm{REV}_{\mathrm{i}, \mathrm{t}} / \mathrm{TA}_{\mathrm{i}, \mathrm{t}-1}+\delta_{4} \mathrm{ROA}_{\mathrm{i}, \mathrm{t}}+\varepsilon_{\mathrm{i}, \mathrm{t}}
$$

The residual value of the estimated Eq. (2) shows the magnitude of discretionary accruals. This study follows discretionary accruals at an aggressive level used by Greiner et al. (2017), i.e., Q1DA as an indicator variable, equal to 1 if discretionary accruals are at the top quintile per industry-year rankings; and 0 otherwise (Greiner et al., 2017). The following model is used to test hypothesis $\mathrm{H}_{2 \mathrm{a}}$ and $\mathrm{H}_{2 \mathrm{~b}}$ :

$$
\begin{aligned}
& \text { Q1REM i,t }=\alpha_{1}+\alpha_{2} \text { PARTNER_SPCL }_{\mathrm{i}, \mathrm{t}}+\alpha_{3} \text { CI_PARTNER }_{\mathrm{i}, \mathrm{t}}+\alpha_{4} \text { FIRM_SPCL }_{\mathrm{i}, \mathrm{t}} \\
& +\alpha_{5} \text { CI_FIRM }{ }_{i, t}+\alpha_{6} \overline{B I G F O U R}_{\mathrm{i}, \mathrm{t}}+\alpha_{7} \text { SIZE }_{\mathrm{i}, \mathrm{t}}+\alpha_{8} \text { LEVERAGE }_{\mathrm{i}, \mathrm{t}}+\alpha_{9} \text { LOSS }_{\mathrm{i}, \mathrm{t}} \\
& +\alpha_{10} \mathrm{CFO}_{\mathrm{i}, \mathrm{t}}+\alpha_{11} \mathrm{GROWTH}_{\mathrm{i}, \mathrm{t}}+\alpha_{12} \mathrm{BTM}_{\mathrm{i}, \mathrm{t}}+\alpha_{13} \mathrm{ROA}_{\mathrm{i}, \mathrm{t}}+\alpha_{14} \mathrm{DROA}_{\mathrm{i}, \mathrm{t}} \\
& +\alpha_{15} \text { AGE i,t }+\alpha_{16} \mathrm{Q}_{1 D A_{i, t}}+\delta_{\mathrm{j}} \text { YEAR }+\sigma_{\mathrm{k}} \text { INDUSTRY }+\varepsilon_{\mathrm{i}} \text {, }
\end{aligned}
$$

where: PARTNER_SPCL and FIRM_SPCL are expected to be negatively associated with real transaction activities (Q1REM) reflected by negative and significant coefficients of $\alpha_{2}$ and $\alpha_{4}$. Following the previous model (e.g., Kim and Park, 2014; Roychowdhury, 2006), REM is an aggregate value of the sum of real activities at an individual level, i.e., abnormal CFO, abnormal production, and abnormal discretionary expense. Furthermore, following Greiner et al. (2017), REM values are ranked according to the industry and year related to reflect the auditor's most significant risk. The Q1REM is an indicator variable, equal to 1 if REM is at the highest quintile per industry-year ranking in the data distribution, and 0, otherwise. The following model is used to test hypothesis $\mathrm{H}_{3 \mathrm{a}}$ and $\mathrm{H}_{3 b}$ :

$$
\begin{aligned}
& \mathrm{MAO}_{\mathrm{i}, \mathrm{t}}=\mu_{1}+\mu_{2} \text { PARTNER_SPCL }_{\mathrm{i}, \mathrm{t}}+\mu_{3} \text { CI_PARTNER }_{\mathrm{i}, \mathrm{t}}+\mu_{4} \text { FIRM_SPCL }_{\mathrm{i}, \mathrm{t}}+\mu_{5} \text { CI_FIRM }_{\mathrm{i}, \mathrm{t}} \\
& +\mu_{6} \text { BIGFOUR }_{i, t}+\mu 7 \text { SIZE }_{i, t}+\mu \text { LEVERAGE }_{i, t}+\mu 9 \text { LOSS }_{i, t}+\mu 10 \text { LAGLOSS }_{i, t} \\
& +\mu 11_{\text {CFO }_{i, t}}+\mu 12 \text { GROWTH }_{i, t}+\mu 13 \text { BTM }_{i, t}+\mu 14 \text { ROA }_{i, t}+\mu 15 \text { DROA }_{i, t} \\
& +\mu 16 \mathrm{AGE}_{\mathrm{i}, \mathrm{t}}+\delta_{\mathrm{j}} \mathrm{YEAR}+\sigma_{\mathrm{k}} \text { INDUSTRY }+\varepsilon_{\mathrm{i}, \mathrm{t}}
\end{aligned}
$$

where: MAO is a modified audit opinion, a dummy variable equal to 1 if the auditor issues a type of audit opinion other than the standard unmodified opinion, and 0 if others. Coefficients $\mu 2$ of $\mathrm{H} 3 \mathrm{a}$ and $\mu 4$ of $\mathrm{H} 3 \mathrm{~b}$ are expected to be positive and significant, which indicates high audit quality from the engagement partners and audit firms with industry specialization.

\subsubsection{Measurement of real earnings management (Q1REM)}

To obtain the aggregate value of REM, we first calculated REM components at an individual level, i.e., abnormal CFO, abnormal production cost, and abnormal discretionary expense following the previous studies (e.g., Kim and Park, 2014; Roychowdhury, 2006). This study uses the following model to calculate the abnormal CFO:

$$
\mathrm{CFO}_{\text {it }}=\alpha_{0}+\alpha_{1}\left(1 / \mathrm{A}_{\mathrm{it}-1}\right)+\beta_{1}\left(\mathrm{~S}_{\mathrm{it}} / \mathrm{A}_{\mathrm{it}-1}\right)+\beta_{2}\left(\Delta \mathrm{S}_{\mathrm{it}} / \mathrm{A}_{\mathrm{it}-1}\right)+\varepsilon_{\mathrm{it}}
$$

Abnormal values of CFO (AB_CFO) can be calculated based on the difference between the estimated results of Eq. (5) and the actual value of CFO or obtained from the residual value of Eq. (5). All variables in Eq. (5) are scaled with total assets t-1. The following model is used to calculate the abnormal production cost:

$$
\operatorname{PROD}_{i t}=\alpha_{0}+\alpha_{1}\left(1 / \mathrm{A}_{\mathrm{it}-1}\right)+\beta_{1}\left(\mathrm{~S}_{\mathrm{it}} / \mathrm{A}_{\mathrm{it}-1}\right)+\beta_{2}\left(\Delta \mathrm{S}_{\mathrm{it}} / \mathrm{A}_{\mathrm{it}-1}\right)+\beta_{3}\left(\Delta \mathrm{S}_{\mathrm{it}-1} / \mathrm{A}_{\mathrm{it}-1}\right)+\varepsilon_{\mathrm{it}}
$$


PROD is the sum of the value of the cost of goods sold and changes in inventory. Abnormal production cost (AB PROD) can be calculated based on the difference between the estimation results of Eq. (6) and actual production cost (PROD) or obtained from the residual value of Eq. (6). Furthermore, to calculate the abnormal discretionary expense, the following model is used:

$$
\operatorname{DISEXP}_{\mathrm{it}}=\alpha_{0}+\alpha_{1}\left(1 / \mathrm{A}_{\mathrm{it}-1}\right)+\beta_{2}\left(\Delta \mathrm{S}_{\mathrm{it}-1} / \mathrm{A}_{\mathrm{it}-1}\right)+\varepsilon_{\mathrm{it}}
$$

DISEXP is the sum of R\&D costs, promotion costs, and SG\&A (Kim \& Park, 2014). Abnormal discretionary expense (AB_DEXP) is the difference between the estimated results of Eq. (7) and the actual value of discretionary expense (DISEXP) or obtained from the residual errors of Eq. (7). Following Kim and Park (2014), the value of REM is the sum of REM activities at the individual level, i.e. (AB_PROD - AB_CFO - AB_DEXP).

\subsubsection{Measurement of industry specialization (PARTNER_SPCL, FIRM_SPCL)}

Industry specialization is defined based on the auditor's market share (Francis et al., 2004; Gul et al., 2009). Following the previous studies (Herusetya, 2012; Gul et al., 2009; Khrisnan, 2003; Balsam et al., 2003), industry market share at the partner and audit firm levels is based on the total client assets in each industry. PARTNER_SPCL is a dummy variable, equal to 1 if a partner has the most significant industry share in a given year, and 0 otherwise. The percentage of market shares is measured by the sum of total assets of all clients audited by a particular partner in one industry divided by the sum of total assets of all clients in one industry. FIRM_SPCL is a dummy variable, equal to 1 if a particular audit firm has the most significant industry market share in a given year, and 0 if otherwise. The percentage of market shares is the sum of total client assets of a particular audit firm in one industry divided by the total client assets of all audit firms in a particular industry (Gul et al., 2009; Krishnan, 2003).

\subsubsection{Control variables}

Some control variables also influence discretionary accruals at the aggressive level (Q1DA) in Eq. (1), real earnings management at the aggressive level (Q1REM) in Eq. (2), and modified audit opinion (MAO) in Eq. (3). We use control variable Q1REM in Eq. (1) and Q1DA in Eq. (2), because prior research found that management use accrual earning management and real transactions as substitute or complement to each other (Graham et al., 2005; Zang, 2012; Cohen et al., 2008; Ontorael \& Geraldina, 2017). Client importance, both at the partner level (CI_PARTNER) and audit firm (CI_FIRM) are included as control variables because prior studies report that client importance have a positive or negative effect on discretionary accruals (e.g., Chen et al., 2010; Susanto \& Herusetya, 2014; Gul et al., 2017; Wang et al., 2015), and modified or going concern opinion (e.g., Susanto \& Herusetya, 2014; Defond \& Zhang, 2014; Hossain et al., 2016).

Audit firm size (BIGFOUR) is associated with high audit quality, and hence is negatively associated with discretionary accruals (Becker et al., 1998; Herusetya, 2012) and positively associated with going concern opinion. SIZE and AGE as control variables, because the more significant the size and the longer life of the company are associated with a lower level of discretionary accruals and the acceptance of modified audit opinion (Chi \& Chin, 2011; Menon \& Williams, 2004). Companies with a high level of leverage (LEV) have incentives to increase earnings due to compliance with debt covenant (Chi \& Chin, 2011; Reynold and Francis, 2001). This condition increases the risk for the auditor in which will issue a going concern opinion. Firm-specific growth (GROWTH) is included to distinguish companies that experience rapid growth with lower growth, and growth is related to the accrual model (Carey \& Simnett, 2006; Gul et al., 2009).

We also include loss (LOSS), book to market (BTM), return on assets (ROA) to control operational performance, and financial risk of clients (Gul et al., 2017). Prior year loss (LAGLOSS) and changes in return on assets (DROA) are included as control variables to control the client's higher tendency to accept going concern opinion or MAO (Reynolds \& Francis, 2001, Gul et al., 2017). We include operating cash flow (CFO) because companies with higher operating cash flows have better performance (Myers et al., 2003), and accruals are negatively related to operating cash flows as documented in previous studies (Gul et al., 2009; Dechow et al., 2010).

Real earnings management (Q1REM) is included as a control variable in Equation (1) and (2) because management uses these tools as a combination or trade- off in earnings management (Graham et al., 2005; Cohen et al., 2008; Zang, 2012; Burnett et al., 2012; Greiner et al., 2017). Total accruals (TACC) is positively related to discretionary accruals (Balsam et al., 2003). To reduce the potential influence of industry and year on discretionary accruals and real earnings management at an aggressive level and modified audit opinion, we include the fixed effects of YEAR and INDUSTRY (Fama \& French, 1997) (See Table 2 for the details of variables). 


\section{Table 2}

\section{Definition of variables}

\begin{tabular}{|c|c|c|}
\hline Variables & & Definition \\
\hline \multicolumn{3}{|l|}{ Equation (1), (3), (4) } \\
\hline Q1DA & $=$ & $\begin{array}{l}\text { Aggressive discretionary accruals, a measure of audit quality. Following Greiner et al. (2017), Q1DA equal to 1, if } \\
\text { discretionary accruals are at the top quintile per industry-year rankings; and } 0 \text { otherwise. Discretionary accruals are } \\
\text { estimated from the Jones (1991) model, modified by Dechow et al. (1995), and implemented by Tucker and Zarowin } \\
\text { (2006): TACCi,t/TAi,t-1 }=\delta 0+\delta 1 \text { 1/TAi,t-1 }+\delta 2 \text { GPPEi,t/TAi,t-1 }+\delta 3 \Delta \text { REVi, t/TAi,t-1 }+\delta 4 \text { ROAi,t }+\varepsilon i, t \text { (Eq. } 2)\end{array}$ \\
\hline Q1REM & $=$ & $\begin{array}{l}\text { Aggressive real earnings management, a measure of audit quality. Following Greiner et al. (2017), Q1REM equal to } 1 \text {, if } \\
\text { REM is at the top quintile per industry-year rankings, and } 0 \text { otherwise. Following Kim and Park (2014) and } \\
\text { Roychowdhury (2006), REM is the aggregate value of the sum of real activities at the individual level, i.e., abnormal } \\
\text { CFO (AB_CFO), abnormal production (AB_PROD), and abnormal discretionary expense (AB_DEXP) calculated in } \\
\text { Equation (5), (6), (7), respectively }\end{array}$ \\
\hline MAO & $=$ & $\begin{array}{l}\text { Dummy variable (modified audit opinion), equal to } 1 \text { if the firm receives a type of audit opinion other than standard } \\
\text { unmodified opinion, } 0 \text { otherwise }\end{array}$ \\
\hline PARTNER_SPCL & $=$ & $\begin{array}{l}\text { Dummy variable, equal to } 1 \text {, if a partner } \mathrm{j} \text { has the largest percentage of market share in industry } \mathrm{k} \text { in year } \mathrm{t} ; 0 \text { otherwise. } \\
\text { The percentage of market share is the sum of total assets of all clients audited by partner } \mathrm{j} \text { in industry } \mathrm{k} \text { divided by the } \\
\text { sum of total assets of clients audited by all partners in industry } \mathrm{k} \text {. }\end{array}$ \\
\hline FIRM_SPCL & $=$ & $\begin{array}{l}\text { Dummy variable, equal to } 1 \text {, if audit firm } \mathrm{m} \text { has the most significant percentage of market share in industry } \mathrm{k} \text { in year } \mathrm{t} ; 0 \\
\text { otherwise. The percentage of market share is the sum of total assets of all clients audited by audit firm } \mathrm{m} \text { in industry } \mathrm{k} \\
\text { divided by the sum of total assets of clients audited by all audit firms in industry } \mathrm{k} \text {. }\end{array}$ \\
\hline CI_PARTNER & $=$ & $\begin{array}{l}\text { Client importance at the partner level. Following Chen et al. (2010), percentage of CI is measured by total assets of the } \\
\text { client } \mathrm{i} \text { divided by the sum of total assets audited by partner } \mathrm{j}\end{array}$ \\
\hline CI_FIRM & $=$ & $\begin{array}{l}\text { Client importance at audit firm level. Following Chen et al. (2010), percentage of CI is measured by total assets of the } \\
\text { client } \mathrm{i} \text { audited by audit firm } \mathrm{m} \text { divided by the sum of total client assets audited audit firm } \mathrm{m}\end{array}$ \\
\hline BIGFOUR & $=$ & Dummy variable, 1 if the firm is audited by one of the big 4 audit firms, 0 otherwise \\
\hline SIZE & $=$ & Natural logarithm of assets \\
\hline LEVERAGE & $=$ & Leverage ratio, defined as total liabilities divided by total assets. \\
\hline LOSS & $=$ & Dummy variable, 1 if the firm reported a loss in the current year, 0 otherwise \\
\hline LAGLOSS & $=$ & Dummy variable, 1 if the firm reported a loss in the previous year, 0 otherwise \\
\hline $\mathrm{CFO}$ & $=$ & Cash flows from operating activities \\
\hline GROWTH & $=$ & Sales growth, i.e. (sales t - sales t-1)/sales t-1 \\
\hline BTM & $=$ & Book to market ratio, the ratio of total common shareholder' equity to total market value \\
\hline ROA & $=$ & Return on assets \\
\hline DROA & $=$ & Changes in return on assets \\
\hline AGE & $=$ & Natural logarithm of the number of years \\
\hline TACC & $=$ & Total accruals, i.e. operating income minus cash flows from operating activities \\
\hline YEAR & $=$ & Year dummies \\
\hline INDUSTRY & $=$ & Industry dummies \\
\hline \multicolumn{3}{|l|}{ Eq. (2) } \\
\hline $\mathrm{TACC}$ & $=$ & Total accruals, i.e. operating income minus cash flows from operating activities \\
\hline TA & $=$ & Total assets \\
\hline GPPE & $=$ & Property, Plant, and assets in gross amount \\
\hline$\triangle \mathrm{REV}$ & $=$ & Changes in revenues, i.e. sales t- sales t-1 \\
\hline ROA & $=$ & Return on assets \\
\hline \multicolumn{3}{|l|}{ Equation $(5),(6),(7)$} \\
\hline $\mathrm{CFO}$ & $=$ & Cash flows from operating activities \\
\hline A & $=$ & Total assets \\
\hline $\mathrm{S}$ & $=$ & Sales \\
\hline$\Delta \mathrm{S}$ & $=$ & Changes in sales, i.e. sales $\mathrm{t}-$ sales $\mathrm{t}-1$ \\
\hline PROD & $=$ & The sum of the cost of goods sold and changes in inventory \\
\hline DISEXP & $=$ & The sum of R\&D costs, promotion costs, and SG\&A \\
\hline REM & $=$ & The aggregate value of real activities, i.e. (AB PROD - AB CFO - AB DEXP) \\
\hline
\end{tabular}

\section{Results}

\subsection{Descriptive statistics and correlations}

Table 3 presents information regarding the data set profiles. The mean of industry specialization based on the largest market share at the partner level (PARTNER_SPCL) and the firm level (FIRM_SPCL) are 4.0 percent and 6.1 percent. While the mean of discretionary accrual (DAC) is -2.5 percent of the prior year total assets of the company. The mean of real transaction earnings management at the aggregate level (REM) is 3.7 percent of the prior year's total assets. The mean of the clients to receive a modified audit opinion (MAO) is 21.4 percent. 
Table 3

Descriptive statistics

\begin{tabular}{|c|c|c|c|c|c|c|}
\hline Variables & $\mathrm{n}$ & Mean & standard deviation & First Quartile & Median & Third Quartile \\
\hline DAC & 570 & -0.025 & 0.414 & -0.161 & -0.013 & 0.162 \\
\hline Q1DA & 570 & 0.189 & 0.392 & 0.000 & 0.000 & 0.000 \\
\hline REM & 570 & 0.037 & 0.393 & -0.185 & 0.067 & 0.282 \\
\hline Q1REM & 570 & 0.189 & 0.392 & 0.000 & 0.000 & 0.000 \\
\hline MAO & 570 & 0.214 & 0.410 & 0.000 & 0.000 & 0.000 \\
\hline PARTNER_SPCL & 570 & 0.040 & 0.197 & 0.000 & 0.000 & 0.000 \\
\hline FIRM_SPCL & 570 & 0.061 & 0.240 & 0.000 & 0.000 & 0.000 \\
\hline CI_PĀRTNER & 570 & 0.768 & 0.331 & 0.502 & 1.000 & 1.000 \\
\hline CI_FIRM & 570 & 0.287 & 0.346 & 0.035 & 0.121 & 0.414 \\
\hline BIGFOUR & 570 & 0.558 & 0.497 & 0.000 & 1.000 & 1.000 \\
\hline LNASSET & 570 & 14.364 & 1.599 & 13.331 & 14.137 & 15.136 \\
\hline LEVERAGE & 570 & 0.455 & 0.234 & 0.270 & 0.432 & 0.610 \\
\hline LOSS & 570 & 0.212 & 0.409 & 0.000 & 0.000 & 0.000 \\
\hline LAGLOSS & 570 & 0.188 & 0.391 & 0.000 & 0.000 & 0.000 \\
\hline $\mathrm{CFO}$ & 570 & 0.084 & 0.148 & 0.009 & 0.057 & 0.122 \\
\hline GROWTH & 570 & 0.111 & 0.394 & 0.000 & 0.058 & 0.155 \\
\hline BTM & 570 & 1.148 & 1.542 & 0.232 & 0.672 & 1.590 \\
\hline ROA & 570 & 0.063 & 0.131 & 0.002 & 0.043 & 0.100 \\
\hline DROA & 570 & 0.126 & 1.940 & -0.619 & -0.107 & 0.189 \\
\hline AGE & 570 & 2.830 & 0.744 & 2.833 & 3.091 & 3.219 \\
\hline TACC & 570 & -0.061 & 0.346 & -0.077 & -0.004 & 0.012 \\
\hline
\end{tabular}

Table 4

The results of correlation

\begin{tabular}{|c|c|c|c|c|c|c|c|c|c|c|c|}
\hline & ariables & 1 & 2 & 3 & 4 & 5 & 6 & 7 & 8 & 9 & 10 \\
\hline 1 & Q1DA & 1.000 & & & & & & & & & \\
\hline 2 & Q1REM & $0.075^{*}$ & 1.000 & & & & & & & & \\
\hline 3 & MAO & -0.023 & 0.021 & 1.000 & & & & & & & \\
\hline 4 & PARTNER_SPCL & 0.037 & -0.008 & 0.045 & 1.000 & & & & & & \\
\hline 5 & CI_PARTNER & -0.049 & 0.012 & $0.127 * * *$ & 0.046 & 1.000 & & & & & \\
\hline 6 & FIRM_SPCL & 0.041 & $0.076^{*}$ & $0.125 * * *$ & $0.308^{* * *}$ & 0.052 & 1.000 & & & & \\
\hline 7 & CI_FIRM & $0.074^{*}$ & 0.043 & -0.037 & 0.006 & $0.403 * * *$ & -0.018 & 1.000 & & & \\
\hline 8 & BIGFOUR & $-0.119^{* * *}$ & 0.043 & 0.034 & 0.003 & 0.004 & -0.034 & $-0.181 * * *$ & 1.000 & & \\
\hline 9 & SIZE & $-0.182 * * *$ & -0.025 & 0.028 & -0.040 & -0.020 & -0.044 & 0.058 & -0.002 & 1.000 & \\
\hline 10 & LEVERAGE & 0.003 & $0.212 * * *$ & 0.037 & -0.017 & -0.001 & 0.023 & 0.033 & $0.111^{* * *}$ & 0.036 & 1.000 \\
\hline 11 & LOSS & 0.034 & $0.143 * * *$ & 0.053 & 0.003 & -0.006 & 0.002 & 0.027 & 0.047 & $-0.129 * * *$ & $0.427 * * *$ \\
\hline 12 & LAGLOSS & $-0.118 * * *$ & -0.061 & $0.100 * *$ & -0.053 & 0.056 & -0.005 & -0.028 & 0.030 & 0.033 & 0.033 \\
\hline 13 & CFO & $0.230^{* * *}$ & $-0.310 * * *$ & 0.012 & 0.046 & 0.057 & 0.041 & -0.023 & -0.016 & $0.107 * * *$ & $-0.200 * * *$ \\
\hline 14 & GROWTH & -0.038 & $0.091 * *$ & $-0.79 *$ & 0.032 & -0.017 & -0.036 & -0.058 & 0.009 & 0.000 & 0.003 \\
\hline 15 & BTM & -0.036 & $0.075^{*}$ & -0.051 & -0.057 & $-0.104 * *$ & $-0.117 * * *$ & -0.033 & $-0.098 * *$ & 0.023 & -0.008 \\
\hline 16 & ROA & $-0.100 * *$ & $-0.146^{* * *}$ & 0.010 & 0.014 & 0.028 & -0.010 & -0.047 & -0.013 & $0.202 * * *$ & $-0.380 * * *$ \\
\hline 17 & DROA & 0.037 & -0.016 & 0.040 & -0.023 & -0.038 & -0.043 & $-0.093 * *$ & 0.000 & -0.020 & $0.088^{* *}$ \\
\hline 18 & AGE & $-0.080^{*}$ & 0.049 & -0.017 & -0.035 & 0.040 & 0.046 & -0.022 & $0.103 * *$ & 0.057 & 0.017 \\
\hline 19 & TACC & $0.350 * * *$ & $0.190 * * *$ & -0.057 & -0.020 & $0.070 *$ & -0.019 & $-0.113^{* * *}$ & 0.005 & $-0.097 * *$ & $-0.097 * *$ \\
\hline
\end{tabular}

Table 4

The results of correlation

\begin{tabular}{|c|c|c|c|c|c|c|c|c|c|c|}
\hline & bles & 11 & 12 & 13 & 14 & 15 & 16 & 17 & 18 & 19 \\
\hline 11 & LOSS & 1.000 & & & & & & & & \\
\hline 12 & LAGLOSS & 0.047 & 1.000 & & & & & & & \\
\hline 13 & $\mathrm{CFO}$ & $-0.240 * * *$ & -0.052 & 1.000 & & & & & & \\
\hline 14 & GROWTH & $-0.138 * * *$ & -0.020 & -0.011 & 1.000 & & & & & \\
\hline 15 & BTM & 0.011 & -0.049 & -0.011 & 0.055 & 1.000 & & & & \\
\hline 16 & ROA & $-0.507 * * *$ & -0.068 & $0.511 * * *$ & $0.086^{* *}$ & 0.032 & 1.000 & & & \\
\hline 17 & DROA & -0.056 & $-0.077^{*}$ & 0.009 & 0.032 & 0.005 & $0.087 * *$ & 1.000 & & \\
\hline 18 & AGE & 0.020 & -0.031 & $0.155 * * *$ & 0.004 & -0.025 & $0.131 * * *$ & 0.027 & 1.000 & \\
\hline 19 & TACC & $-0.117 * * *$ & $-0.105 * * *$ & $-0.281 * * *$ & 0.068 & $0.079 *$ & $0.146 * * *$ & 0.037 & -0.046 & 1.000 \\
\hline
\end{tabular}


The correlation between variables used in this study, as reported in Table 4 shows that industry specialization at the partner level (PARTNER_SPCL) and the firm level (FIRM_SPCL) to discretionary accruals at aggressive levels (Q1DA) was not significant at 0.10 , respectively. The industry specialization at the partner level (PARTNER_SPCL) towards aggressive real earnings management (Q1REM) is not significant, while at the firm level (FIRM_SPCL), it is positive and significant at 0.10. Furthermore, industry specialization at the partner level (PARTNER_SPCL) towards the client's likelihood to accept MAO is not significant, but industry specialization at the firm level (FIRM_SPCL) is positive and significant at 0.01 . The results of this univariate analysis provide initial support for the next hypothesis test. The client importance at the partner level (CI_PARTNER) is positively associated with MAO at 0.01, but not with Q1DA and Q1REM. On the other hand, the client importance at the firm level (CI_FIRM) is positive and significant at 0.10 toward Q1DA, but not significant to Q1REM and MAO at 0.10. Other control variables are significant according to the initial prediction of Q1DA, Q1REM, and MAO.

\subsection{Regression results of aggressive discretionary accruals (Q1DA)}

Table 5 presents the logistic regression results of hypothesis H1a and H1b. Columns (1) and (2) report the regression results of the influence of industry specialization at the partner level (PARTNER_SPCL) and audit firm level (FIRM_SPCL) on aggressive discretionary accruals (Q1DA), respectively. The two coefficients of PARTNER_SPCL $(0.511$, p-value $=0.43)$ and FIRM_SPCL $(0.061$, p-value $=0.86)$ are not significant at 0.10 , respectively. Column $(3)$ reveals the primary model of interest, i.e., Equation (1). It reveals that the coefficients of partner specialization $(0.584, \mathrm{p}$-value $=0.39)$ and audit firm specialization $(0.021, \mathrm{p}$-value $=0.96)$ both are not significant at 0.10 . The results do not support the hypothesis H1a and H1b, because they found no evidence of the associations between industry specialization both at the partner level (PARTNER_SPCL) and the firm level (FIRM_SPCL) and the aggressive accrual earnings management, after controlling the client importance both at the partner level (CI_PARTNER) and the firm level (CI_FIRM), aggressive real earnings management (Q1REM), and other control variables. This finding concludes that industrial expertise owned by the engagement partners and audit firms is not associated with higher audit quality concerning aggressive accrual-based earnings management. The results of this study are in line with Abodia et al. (2016) using Big Four data in the United States where they found no association between industry specialization partners and several audit quality proxies, including accruals, audit deficiencies scrutinized by PCAOB inspectors, meetings/beating the zero earnings threshold, and accounting restatements.

\section{Table 5}

Logistic regression results of $\mathrm{H} 1 \mathrm{a}$ and $\mathrm{H} 1 \mathrm{~b}$

\begin{tabular}{|c|c|c|c|c|c|c|c|}
\hline \multirow{3}{*}{ Independent Variables } & \multirow{3}{*}{$\begin{array}{c}\text { Dependent } \\
\text { Variable }\end{array}$} & \multicolumn{6}{|c|}{ Q1DA } \\
\hline & & \multicolumn{2}{|c|}{ Column (1) } & \multicolumn{2}{|c|}{ Column (2) } & \multicolumn{2}{|c|}{ Column (3) } \\
\hline & & Coeff. & z-test & Coeff. & Z-test & Coeff. & z-test \\
\hline PARTNER_SPCL & - & 0.511 & 0.78 & & & 0.584 & 0.87 \\
\hline FIRM_SPCL & - & & & 0.061 & 0.18 & 0.021 & 0.06 \\
\hline PARTNERE_SPCL $x$ CI_PARTNER & $?$ & & & & & & \\
\hline FIRM_SPCL $x$ CI_FIRM & $?$ & & & & & & \\
\hline CI_PĀRTNER & $?$ & -0.407 & -1.01 & & & $-1.013 * *$ & -2.26 \\
\hline CI_FIRM & $?$ & & & $0.935 * *$ & 2.29 & $1.362 * * *$ & 3.02 \\
\hline BIGFOUR & - & $-0.817 * * *$ & -3.10 & $-0.672 * * *$ & -2.48 & $-0.708 * * *$ & -2.57 \\
\hline SIZE & - & $-0.726 * * *$ & -5.63 & $-0.731 * * *$ & -5.79 & $-0.765 * * *$ & -5.81 \\
\hline LEVERAGE & + & 0.093 & 0.15 & $0.109^{*}$ & 0.17 & 0.039 & 0.06 \\
\hline LOSS & - & -0.082 & -0.22 & -0.080 & -0.22 & -0.032 & -0.09 \\
\hline $\mathrm{CFO}$ & - & -2.964 & -1.60 & $-2.959 *$ & -1.65 & -3.067 & -1.62 \\
\hline GROWTH & + & -0.312 & -0.73 & -0.308 & -0.308 & -0.309 & -0.67 \\
\hline BTM & - & -0.131 & -1.49 & -0.122 & -1.35 & -0.138 & -1.54 \\
\hline ROA & - & $-3.219^{*}$ & -1.75 & $-3.321 *$ & -1.85 & -3.052 & -1.59 \\
\hline DROA & + & 0.014 & 0.25 & 0.028 & 0.52 & 0.029 & 0.52 \\
\hline AGE & - & -0.233 & -1.38 & -0.235 & -1.33 & -0.222 & -1.31 \\
\hline Q1REM & $?$ & -0.096 & -0.27 & -0.216 & -0.59 & -0.171 & -0.46 \\
\hline TACC & + & $6.551 * * *$ & 6.28 & $6.861 * * *$ & 6.59 & $6.857 * * *$ & 6.24 \\
\hline YEAR & $?$ & Yes & & Yes & & Yes & \\
\hline INDUSTRY & $?$ & Yes & & Yes & & Yes & \\
\hline CONSTANT & $?$ & $9.842 * * *$ & 5.08 & $9.293 * * *$ & 5.11 & $10.343^{* * *}$ & 5.22 \\
\hline $\mathrm{N}$ & & & 570 & & 570 & & 570 \\
\hline Wald chi2 & & & 91.69 & & 91.35 & & 95.36 \\
\hline Prob $>$ chi 2 & & & 0.00 & & 0.00 & & 0.00 \\
\hline Pseudo R2 & & & 0.3170 & & 0.3248 & & 0.3352 \\
\hline
\end{tabular}

The results of this study differ from the previous studies that auditor or audit firm with industry specialization is associated with lower accrual earnings management compared to the auditor or audit firm without industry specialization (e.g., Herusetya, 2012; 
2009a; 2009b; Balsam et al., 2003; Krishnan, 2003; Gul et al., 2009). These results were also different from, e.g., Chi and Chin (2011), who found evidence that industry specialization at partner level and audit firm level is associated with smaller discretionary accruals.

\subsection{Regression results of aggressive real earnings management (Q1REM)}

Table 6 shows the logistic regression results of hypothesis H2a and H2b. Columns (1) reports that the coefficient of specialization industry at the partner level (PARTNER_SPCL) is not significant $(0.354$, p-value $=0.62)$. While Column (3) reveals the results for Equation (3) and is the main model of interest. The coefficient of specialization industry at the partner level (PARTNER_SPCL) is not significant $(0.040, \mathrm{p}$-value $=0.96)$ at 0.10 . The results show that industry specialization at the partner level (PARTNER_SPCL) does not have any relation with aggressive real earnings management (Q1REM). So it does not support the H2a. Column (2) shows that the coefficient of audit firm industry specialization (FIRM_SPCL) alone is positive and significant at $0.05(0.671, \mathrm{p}$-value $=0.03)$. Column $(3)$ reports the result of the primary model of interest. It reveals that the coefficient of audit firm industry specialization (FIRM_SPCL) is positive and significant at $0.05($ Column 3$)(0.655$, p-value $=$ 0.04). The result differs in direction from the expectation of H2b, where industry specialization at the firm level (FIRM_SPCL) has a positive relationship with real earnings management at an aggressive level. Our results are in line with Chi et al. (2011), who found that as a consequence of high audit quality of audit firms, it encouraged companies to conduct real earnings management. They found evidence that audit fees and auditor with city-level industry specialization were associated with increasing real earnings management levels. It can be understood that accrual-based earnings management is more easily detected by auditors including auditors who have industrial expertise, so that management switches to real earnings management that is more difficult to detect by auditors (Burnett et al., 2012; Cohen et al., 2008; Zang, 2012; Fan et al., 2010, Graham et al., 2005; Barton and Simko, 2002). Furthermore, Chi et al. (2011) found a positive relationship between city-level industry auditor specialists and the size of real earnings management would be stronger for the sample with earnings management that increased (aggressively) compared to samples that did not have such incentives.

\section{Table 6}

Logistic regression results of $\mathrm{H} 2 \mathrm{a}$ and $\mathrm{H} 2 \mathrm{~b}$

\begin{tabular}{|c|c|c|c|c|c|c|c|}
\hline \multirow{3}{*}{ Independent Variables } & \multicolumn{3}{|l|}{$\begin{array}{l}\text { Dependent } \\
\text { Variable }\end{array}$} & \multicolumn{2}{|c|}{ Q1REM } & & \\
\hline & \multirow{2}{*}{ Predicted sign } & \multicolumn{2}{|c|}{ Column (1) } & \multicolumn{2}{|c|}{ Column (2) } & \multicolumn{2}{|c|}{ Column (3) } \\
\hline & & Coeff. & z-test & Coeff. & z-test & Coeff. & z-test \\
\hline PARTNER_SPCL & - & 0.354 & 0.50 & & & 0.040 & 0.05 \\
\hline FIRM_SPCL & - & & & $0.671 *$ & 2.14 & $0.655^{* *}$ & 2.04 \\
\hline PARTNER_SPCL $x$ CI_PARTNER & $?$ & & & & & & \\
\hline FIRM_SPCL x CI_FIRM & $?$ & & & & & & \\
\hline CI_PARTNER & $?$ & 0.544 & 1.39 & & & 0.311 & 0.71 \\
\hline CI_FIRM & $?$ & & & $0.643 *$ & 1.87 & 0.518 & 1.35 \\
\hline BIGFOUR & - & -0.086 & -0.34 & 0.007 & 0.03 & -0.006 & -0.02 \\
\hline SIZE & - & 0.035 & 0.45 & 0.027 & 0.35 & 0.032 & 0.41 \\
\hline LEVERAGE & + & $1.735 * * *$ & 2.86 & $1.681 * * *$ & 2.79 & $1.685 * * *$ & 2.79 \\
\hline LOSS & - & 0.063 & 0.19 & 0.106 & 0.32 & 0.100 & 0.30 \\
\hline $\mathrm{CFO}$ & - & $-1.311 * * *$ & -6.56 & $-1.282 * * *$ & -6.64 & $-1.367 * * *$ & -6.60 \\
\hline GROWTH & + & $0.481 *$ & 1.79 & $0.521 *$ & 1.90 & $0.519 *$ & 1.90 \\
\hline BTM & - & 0.119 & 1.38 & 0.130 & 1.43 & 0.136 & 1.51 \\
\hline ROA & - & $2.886^{* *}$ & 2.28 & $3.234 * * *$ & 2.57 & $3.152 * * *$ & 2.51 \\
\hline DROA & + & -0.011 & -0.20 & -0.003 & -0.06 & -0.001 & -0.03 \\
\hline AGE & - & $0.467 * *$ & 2.38 & $0.445^{* *}$ & 2.24 & $0.447 * *$ & 2.28 \\
\hline Q1DAC & $?$ & -0.203 & -0.62 & -0.291 & -0.88 & -0.277 & -0.85 \\
\hline YEAR & $?$ & Yes & & Yes & & Yes & \\
\hline INDUSTRY & $?$ & Yes & & Yes & & Yes & \\
\hline CONSTANT & & $-4.271 * * *$ & -3.42 & $-4.058 * * *$ & -3.28 & $-4.322 * * *$ & -3.37 \\
\hline $\mathrm{N}$ & & & 570 & & 570 & & 570 \\
\hline Wald chi2 & & & 75.57 & & 83.45 & & 84.90 \\
\hline Prob $>$ chi 2 & & & 0.00 & & 0.00 & & 0.00 \\
\hline Pseudo R2 & & & 0.2336 & & 0.2420 & & 0.2430 \\
\hline
\end{tabular}

***,**,* Indicate significance at the $0.01,0.05$ and 0.10 levels, respectively. All variables are described in Table 2 .

Table 6, Column (3) reports the results of control variables. It shows that client importance at the partner level (CI_PARTNER) and at the firm level (CI_FIRM) are not significant. The coefficient of leverage (LEV) is significant at 0.01 (1,685, p-value $<0.01)$. The coefficient of CFO is negative and significant at $0.01(-15.367$, p-value $<0.01)$, GROWTH is significant at 0.10 $(0.519, \mathrm{p}$-value $=0.06)$, return on assets $(\mathrm{ROA})$ is significant at $0.01(3.152, \mathrm{p}$ - value $<0.01)$, and AGE is significant at 0.05 $(0.447, \mathrm{p}$-value $=0.02)$. 
Table 7 reports the logistic regression results of hypothesis H3a and H3b. Columns (1) and (3) show the coefficients of industry specialization at the partner level (PARTNER_SPCL) is not significant at $0.10(0.517, \mathrm{p}$-value $=0.30$, and 0.079 , p-value $=$ 0.89). The test results of H3a, i.e., Column (3) for Equation (3) found no evidence that industry specialization at the partner level (PARTNER_SPCL) was associated with a modified audit opinion (MAO). The results of this study are different from Chi and Chin (2011), who found evidence that clients with signing partners (lead auditors and concurring auditors) who specialize in industries tend to accept MAO. Nevertheless, the results of this study are in line with Abodia et al. (2016), who did not find any association between industry specialization at the partner level for company data audited by Big Four and several audit quality proxies.

\section{Table 7}

Logistic regression results of $\mathrm{H} 3 \mathrm{a}$ and $\mathrm{H} 3 \mathrm{~b}$

\begin{tabular}{|c|c|c|c|c|c|c|c|}
\hline \multirow{3}{*}{ Independent Variables } & \multicolumn{3}{|l|}{$\begin{array}{l}\text { Dependent } \\
\text { Variable }\end{array}$} & \multicolumn{2}{|c|}{ MAO } & & \\
\hline & \multirow{2}{*}{ Predicted sign } & \multicolumn{2}{|c|}{ Column (1) } & \multicolumn{2}{|c|}{ Column (2) } & \multicolumn{2}{|c|}{ Column (3) } \\
\hline & & Coeff. & z-test & Coeff. & z-test & Coeff. & z-test \\
\hline PARTNER_SPCL & + & 0.517 & 1.03 & & & 0.079 & 0.14 \\
\hline FIRM_SPCL & + & & & $0.750 * * *$ & 2.91 & $0.707 * * *$ & 2.50 \\
\hline PARTNER_SPCL x CI_PARTNER & ? & & & & & & \\
\hline FIRM_SPCL x CI_FIRM & ? & & & & & & \\
\hline CI_PARTNER & $?$ & $0.998 * * *$ & 2.84 & & & $1.264 * * *$ & 3.29 \\
\hline CI_FIRM & $?$ & & & -0.231 & -0.75 & $-0.670 * *$ & -1.93 \\
\hline BIGFOUR & + & 0.138 & 0.64 & 0.141 & 0.65 & 0.098 & 0.44 \\
\hline SIZE & - & 0.041 & 0.59 & 0.049 & 0.71 & 0.063 & 0.90 \\
\hline LEVERAGE & + & 0.266 & 0.50 & 0.221 & 0.42 & 0.261 & 0.48 \\
\hline LOSS & + & 0.330 & 1.05 & 0.381 & 1.22 & 0.360 & 1.13 \\
\hline LAGLOSS & + & $0.516^{* *}$ & 2.00 & $0.54 * *$ & 2.13 & $0.496^{*}$ & 1.92 \\
\hline $\mathrm{CFO}$ & - & 0.013 & 0.02 & 0.065 & 0.08 & -0.090 & -0.10 \\
\hline GROWTH & - & -0.528 & -1.60 & -0.494 & -1.52 & $-0.523 *$ & -1.65 \\
\hline BTM & + & -0.055 & -0.77 & -0.058 & -0.81 & -0.040 & -0.55 \\
\hline ROA & - & 1.023 & 1.05 & 1.129 & 1.14 & 1.017 & 1.01 \\
\hline DROA & + & 0.059 & 1.15 & 0.057 & 1.06 & 0.060 & 1.14 \\
\hline AGE & - & -0.153 & -1.09 & -0.164 & -1.19 & -0.183 & -1.29 \\
\hline YEAR & $?$ & Yes & & Yes & & Yes & \\
\hline INDUSTRY & $?$ & Yes & & Yes & & Yes & \\
\hline CONSTANT & $?$ & $-2.858 * * *$ & -2.63 & $-2.252 * * *$ & -2.15 & $-3.220 * * *$ & -2.92 \\
\hline $\mathrm{N}$ & & & 570 & & 570 & & 570 \\
\hline Wald chi2 & & & 30.80 & & 29.72 & & 41.16 \\
\hline Prob $>$ chi 2 & & & 0.00 & & 0.00 & & 0.00 \\
\hline Pseudo R2 & & & 0.0460 & & 0.0451 & & 0.0645 \\
\hline
\end{tabular}

Table 7 shows the test results of H3b. Column (2) reveals that the coefficient of industry specialization at the firm level (FIRM_SPCL) alone is positive and significant at $0.01(0.750$, p- value $<0.01)$. While Column (3) as the main model of interest reveals that the coefficient of industry specialization at the firm level (FIRM_SPCL) is positive and significant at 0.01 (0.707, p-value <0.01). This joint-test results in Column (3) show evidence that there is a positive relation between industry specialization at the firm level (FIRM_SPCL) and the likelihood to issue modified audit opinions (MAO). The results imply that the higher audit quality using industry specialization at the firm level (FIRM_SPCL) is associated with the higher likelihood of audit firm with an industry specialization to issue modified audit opinion (MAO). This finding is consistent with previous studies that found that industry specialization at the firm level is associated with a higher likelihood to issue modified audit opinion (MAO) (e.g., Chi and Chin, 2011). Some of the control variables in Column (3) affect modified audit opinion (MAO) consistent with their initial prediction. The coefficient of client importance at the partner level (CI_PARTNER) is significant at $0.01(1,264$, p-value $<0.01)$, while the coefficient of client importance at firm level (CI_FIRM) is significant at $0.05(-0.670$, pvalue $=0.05)$. LAGLOSS is significant at $0.10(0.496, p$-value $=0.06)$. GROWTH is significant at $0.10(-0.523$, $p$-value $=0.10)$.

\subsection{Robustness tests}

\subsubsection{Hla and H1b sensitivity tests}

Sensitivity test results (not tabulated) using industry specialization criteria at partner level and firm-level with a threshold of 10 percent market share (Niel and Riley, 2004; Balsam et al., 2003) found no evidence of the associations of industry specialization, 
both at partner level and firm level, and aggressive accrual earnings management (Q1DA). Other sensitivity tests (not tabulated) using a combined market share of three industries (i.e., primary and chemical industries, various industries, and consumer goods industries) as a basis for determining industry specialization criteria also found no evidence of any associations. Furthermore, additional testing of DAC (discretionary accruals) replacing the Q1DA using multiple regression (not tabulated) found no evidence of the influence of industry specialization, both at partner level and firm level. Overall, these sensitivity tests support the main results above.

\subsubsection{H2a and H2b sensitivity tests}

Sensitivity test results (not tabulated) using a threshold of 10 percent market share found an association between industry specialization at the partner level (PARTNER_SPCL) and Q1REM, different from the main results of H2a. The combined test results from three industries (not tabulated) found no association. Additional testing using multiple regression of real earnings management (REM) instead of Q1REM (not tabulated) did not find any association. Other results (not tabulated) using a threshold of 10 percent market share, and a combination of three industries at the firm level (FIRM_SPCL) found no association between industry specialization at the firm level with aggressive real earnings management (Q1REM), in contrast to the primary test of H2b. Additional testing results using multiple earnings of real regression management (REM) replacing the Q1REM also found no association.

\subsubsection{H3a and H3b sensitivity tests}

The sensitivity test results (not tabulated) using a 10 percent threshold and a combination of three industries at the partner level (PARTNER_SPCL) did not find any association between industry specialization at the partner level and the likelihood to issue modified audit opinion (MAO). Other sensitivity tests (not tabulated) using going concern opinion (GCO) instead of MAO also found no association. The sensitivity test results using a 10 percent threshold at the firm level found a positive association, consistent with the main H3a results. However, no evidence was found when using a combined market share of three industries to determine the industry specialization criteria at the firm level. Furthermore, the results of sensitivity analysis using going concern opinion (GCO) as a substitute for MAO also did not find any association. Chi and Chin (2011) found that clients of audit firms with industry specialization alone do not have an association with the likelihood to accept MAO. However, specialization at a firm-level combined with specialization from the lead auditors can have an additional effect rather than just lead auditors with industry specialization.

\section{Conclusions}

This study investigates the association of the industry specialization at the partner level and audit firm level to the audit quality as measured by accrual earnings management and real transactions at an aggressive level, as well as the likelihood to issue modified audit opinions. The test results found no evidence of the association of the industry specialization both at partner level and audit firm level with aggressive accrual earnings management. This study found evidence that industry specialization at the audit firm level was positively associated with the real transactions at an aggressive level, contrary to the hypothesis, but found no association at the partner level. Furthermore, the results also found evidence that industry specialization at the audit firm level had a positive association with the likelihood to issue modified audit opinions, but found no evidence at the partner level. The above findings are robust after considering the sensitivity tests, but readers should interpret the results of this study in light of the following limitation. First, there is no consensus on the various measures of industry specialization research, which are the best and representative (Audousset-Coulier et al., 2014; Francis, 2004). Audousset-Coulier et al. (2016) examined the construct validity of industry specialization measurements based on archival studies from audit research and concluded that there was low internal and external validity of these measurements. Other limitations are proxies of audit quality represented by aggressive earnings management using discretionary accruals and real transactions, and modified audit opinions are sensitive to regression models used.

\section{References}

Abodia, D., Lin, C.J., \& Petacchi, R. (2015). Capital market consequences of audit partner quality. The Accounting Review, 90(6), 2143-2176.

Abodia, D., Siddiqui, S., \& Vinelli, A. (2016). Does Engagement Partner Perceived Expertise Matter? Evidence from the U.S. Operations of the Big 4 Audit Firms. Northwestern University and PCAOB. Available at:

https://papers.ssrn.com/sol3/papers. cfm?abstract_id=2840332
Audousset-Coulier, S., Jeny, A., \& Jiang, L. (2016). The Validity of auditor industry specialization measures. Auditing: A Journal of Practice \& Theory, 35(1), 139-161. 
Balsam, S., Krishnan, J., \& Yang, J.S. (2003). Auditor industry specialization and earnings quality. Auditing: A Journal of Practice \& Theory, 22(2), 71-97.

Barton, J., \& Simko, P.J. (2002). The balance sheet as an earnings management constraint. The Accounting Review, 77, 1-27.

Becker, C.L., Defond, M.L., Jiambalvo, J., \& Subramanyam, K.R. (1998). The effect of audit quality on earnings management. Contemporary Accounting Research, 15, 1-24.

Burke, J.J., Hoitash, R., \& Hoitash, U. (2019). Audit partner identification and characteristics: Evidence from U.S. Form AP Filings. Auditing: A Journal of Practice \& Theory, 38(3), 71-94.

Burnett, B. M., Cripe, B.M., Martin, G.W., \& McAllister, B.P. (2012). Audit quality and the trade-off between accretive stock repurchases and accrual-based earnings management. The Accounting Review, 87(6), 1861-1884.

Carey, P., \& Simnett, R. (2006). Audit partner tenure and audit quality. The Accounting Review, 81(3), 653-676.

Chan, H.K., \& Wu, D. (2011). Aggregate quasi rents and auditor independence: Evidence from audit firm mergers in China. Contemporary Accounting Research, 28(1), 175- 213.

Chen, S., Su, S.Y.J, \& Wu, D. (2010). Client importance, institutional improvements, and audit quality in China: An office and individual auditor level analysis. The Accounting Review, 85(1), 127-158.

Chi, H.Y., \& Chin, C.L. (2011). Firm versus partner measures of auditor industry expertise and effects on auditor quality. Auditing: A Journal of Practice \& Theory, 3(2), 201-229.

Chi, W., Douthett, E.B., \& Lisic, L.L. (2012). Client importance and audit partner independence. Journal of Accounting and Public Policy, 31, 320-336.

Chi, W., Lisic, L.L., \& Pevzner, M. (2011). Is enhanced audit quality associated with greater real earnings management? Accounting Horizons, 25(2), 315-335.

Chin, C.L, \& Chi, H.Y. (2009). Reducing restatements with increased industry expertise. Contemporary Accounting Research, 26(3), 729-765.

Cianci, A.M., Houston, R.W., Montague, N.R., \& Vogel, R. (2017). Audit partner identification: Unintended consequences on audit judgment. Auditing: A Journal of Practice \& Theory, 36(4), 135-149.

Cohen, D., Dey, A., \& Lys, T. (2008). Real and accrual-based earnings management in the Pre and Post Sarbanes Oxley periods. The Accounting Review, 83, 757-787.

Dao, M., Xu, H., \& Liu, L. (2018). The impact of disclosure of audit engagement partners on audit quality: Evidence from the USA. International Journal Audit, 23, 112-124.

DeAngelo, L.E. (1981). Auditor size and audit quality. Journal of Accounting and Economics, 3, 183-199.

Dechow, P.M., Ge, W., \& Schrand, C. (2010). Understanding earnings quality: A review of the proxies, their determinants and their consequences. Journal of Accounting and Economics, 50, 344-401.

Dechow, P.M., Sloan, R.G., \& Sweeney, A.P. (1995). Detecting earnings management. The Accounting Review, 70(2), 193225.

Defond, M., \& Zhang, J. (2014). A review of archival auditing research. Journal of Accounting and Economics, 58, 275-326.

Fama, E., \& French, K. (1997). Industry costs of equity. Journal of Financial Economics, 43, 153-193.

Fan, Y., Barua, A., Cready, W.M., \& Thomas, W.B. (2010). Managing earnings using classification shifting: Evidence from quarterly special items. The Accounting Review, 85(4), 1303-1323.

Fargler, N.L., Hou, W, \& Zhang, J.Z. (2019). Do banks audited by specialists engage in less real activities management? Evidence from repurchases agreements. Auditing: A Journal of Practice and Theory, 38(1), 149-169.

Francis, J.R. (2004). What do we know about audit quality? The British Accounting Review, 36, 345-368.

Graham, J.R., Harvey, C.R., \& Rajgopal, S. (2005). The economic implications of corporate financial reporting. Journal of Accounting and Economics, 40, 3-73.

Greiner, A., Kohlbeck, M.J., \& Smith, T.J. (2017). The relationship between aggressive real earnings management and current and future audit fees. Auditing: A Journal of Practice \& Theory, 36(1), 85-107.

Gul, F.A., Fung, S.Y.K., \& Jaggi, B. (2009). Earning quality: Some evidence on the role of auditor tenure and auditor's industry expertise. Journal of Accounting and Economics, 47, 265-287.

Gul, F.A., Ma, S.N., \& Lai, K. (2017). Busy auditors, partner-client tenure, and audit quality: Evidence from an emerging market. Journal of International Accounting Research, 16(1), 83-105.

Gul, F.A., Wu, D., \& Yang, Z. (2013). Do individual auditors affect audit quality? Evidence from archival data. The Accounting Review, 88(6), 1993-2023.

Herusetya, A. (2009a). The effect of the implementation of corporate governance and external auditors with industry specialties on earnings management. Jurnal Auditing dan Akuntansi Indonesia (JAAI), 13(2), 167-188.

Herusetya, A. (2009b). The effect of auditor size and auditor specialization on earnings quality. Jurnal Akuntansi dan Keuangan Indonesia (JAKI), 6(1), 46-70.

Herusetya, A. (2012). The analysis of audit quality analysis on earnings management: Study of composite measure versus conventional measure approach. Jurnal Akuntansi dan Keuangan Indonesia, 9(2), 117-135.

Hossain, S., Monroe, G.S., Wilson, M., \& Jubb, C. (2016). The Effect of networked clients' economic importance on audit quality. Auditing: A Journal of Practice and Theory, 35, 79-103. 
Hsieh, Y.T., \& Lin, C.J. (2016). Audit firms' client acceptance decisions: does partner-level industry expertise matter? Auditing: A Journal of Practice \& Theory, 35(2), 97-120.

Ittonen, K., Johnstone, K., \& Myllymäki, E. R. (2015). Audit partner public-client specialisation and client abnormal accruals. European Accounting Review, 24(3), 607-633.

Ittonen, K., Vahamaa, E., \& Vahamaa, S. (2013). Female auditors and accruals quality. Accounting Horizons, 27(2), $205-228$.

Ji, A.E., Kumar, K.R., Pei, H., \& Xue, Y. (2019). Does market value auditors' industry specializations? Evidence from the contagious effects of restatements. Accounting Horizons, 33(1), 125-152.

Jones, J.J. (1991). Earnings management during import relief investigations. Journal of Accounting Research, 29(2), $193-228$.

Kim, Y., \& Park, M.S. (2014). Real activities manipulation and auditors' client-retention decisions. The Accounting Review, 89(1), 367-401.

Knechel, W.R., Naiker, V., \& Pacheco, G. (2007). Does auditor industry specialization matter? Evidence from market reaction to auditor switches. Auditing: A Journal of Practice \& Theory, 26(1), 19-45.

Krishnan, G.V. (2003). Audit quality and the pricing of discretionary accruals. Auditing: A Journal of Practice \& Theory, 22(1), 109-126.

Lee, H.S.G, Nagy, A.L., \& Zimmerman, A.B. (2019). Audit partner assignments and audit quality in the United States. The Accounting Review, 94(2), 297-323.

Lennox, C.S., \& Wu, X. (2018). A review of the archival literature on audit partners. Accounting Horizons, 32 (2), 1-35.

Lim, C. Y., \& Tan, H.T. (2008). Non-audit service fees and audit quality: The impact of auditor specialization. Journal of Accounting Research, 46(1), 199-246.

Menon, K., \& Williams, D.D. (2004). Former audit partners and abnormal accruals. The Accounting Review, 79(4), $1095-1118$.

Myers, J., Myers, L., \& Omer, T. (2003). Exploring the term of the auditor-client relationship and the quality of earnings: A case for mandatory auditor rotation? The Accounting Review, 78, 779-799.

Niel, T.L., \& Riley, R.R. (2004). Auditor industry specialist research design. Auditing: A Journal of Practice \& Theory, 23(2), 169-177.

Ontorael, R. \& Geraldina, I. (2017). The trade-off between accrual and real earnings management in Indonesia's publicly listed conventional banks. Jurnal Akuntansi dan Keuangan Indonesia, 14(1), 46 - 61.

Peraturan Pemerintah Republik Indonesia No. 20 Tahun 2015 Tentang Praktik Akuntan Publik.

Available at: https://jdih.kemenkeu.go.id/fullText/2015/20TAHUN2015PP.pdf

Pujilestari, R., \& Herusetya, A. (2013). The effect of audit quality on real earnings management - Strategic revenue recognition. Jurnal Akuntansi dan Keuangan, 15(2), 75- 85.

Reichelt, K.J., \& Wang, D. (2010). National and office-specific measures of auditor industry expertise and effects on audit quality. Journal of Accounting Research, 48(3), 647-686.

Reynolds, K.J., \& Francis, J.R. (2001). Does size matter? The influence of large clients on office- level auditor reporting decisions. Journal of Accounting and Economics, 30(3), 375-400.

Roychowdhury, S. (2006). Earnings management through real activities manipulation. Journal of Accounting and Economics, $42(3), 335-370$.

Stein, S.E. (2019). Auditor industry specialization and accounting estimates: Evidence from assets impairments. Auditing: A Journal of Practice \& Theory, 38(2), 207- 234.

Susanto, A., \& Herusetya, A. (2014). The Impact of client importance on earnings management and going concern opinion: Empirical evidence from Indonesia. Jurnal Akuntansi \& Auditing Indonesia (JAAI), 18(1), 75-88.

Taylor, S.D. (2011). Does audit fee homogeneity exist? Premium and discounts attributable to individual partners. Auditing: $A$ Journal of Practice \& Theory, 30(4), 249- 272.

Tucker, J.W., \& Zarowin, P.A. (2006). Does Income smoothing improve earnings informativeness? The Accounting Review, $81(1), 251-270$.

Wang, Y., Yu, L., \& Zhao, Y. (2015). The association between audit-partner quality and engagement quality: Evidence from financial reporting misstatements. Auditing: A Journal of Practice \& Theory, 34(3), 81-111.

Zang, A.Y. (2012). Evidence on the trade-off between real activities manipulation and accrual- based earnings management. The Accounting Review, 87(2), 675-703. 
(C) 2021 by the authors; licensee Growing Science, Canada. This is an open access article distributed under the terms and conditions of the Creative Commons Attribution (CC-BY) license (http://creativecommons.org/licenses/by/4.0/). 